\title{
Upaya Meningkatkan Pengembangan Lembar Kerja Siswa IPA Terpadu Berbasis Pemanfaatan Laboratorium pada Tema Ciri-Ciri Makhluk Hidup di Kelas VII A SMP Negeri 24 Kota Jambi
}

\author{
Resti Pinna St. Rumahorbo ${ }^{1}$
}

\begin{abstract}
Abstrak: IPA merupakan suatu ilmu yang mempelajari konsep, proses, dan fakta yang ada di alam. IPA menduduki peranan penting dalam pendidikan. IPA berkaitan langsung dengan permasalahan yang ada pada kehidupan sehari-hari baik mengenai proses kehidupan, interaksi dengan lingkungan sekitar dan kegiatan yang dilakukan dalam kehidupan tersebut. Hal yang melatarbelakangi peneliti untuk mengembangkan LKS IPA Terpadu berbasis pemanfatan laboratorium yaitu belum tersedianya bahan ajar IPA Terpadu, kurangnya pemanfaatan laboratorium IPA serta kondisi siswa yang kurang aktif dalam mengikuti proses pembelajaran IPA Terpadu. Penelitian ini bertujuan untuk mengetahui kelayakan IPA Terpadu yang berbasis pemanfaatan laboratorium dan untuk mengetahui apakah LKS tersebut dapat meningkatkan hasil belajar siswa. Metode penelitian yang digunakan adalah Research and Development. Pada tahap validasi oleh validator yang meliputi komponen isi, bahasa dan penyajian diperoleh skor rata-rata 97,56\% menunjukkan LKS ini sangat layak diterapkan dalam pembelajaran. Hal itu didukung tanggapan guru yang mencapai 98,33\% dan tanggapan siswa sebesar $91 \%$ menyatakan bahwa LKS ini sangat menarik dan dapat mendorong siswa untuk lebih aktif dalam pembelajaran. LKS ini dapat meningkatkan hasil belajar kognitif siswa mencapai 0,71 yang merupakan kriteria peningkatan tinggi. Dari analisis tersebut disimpulkan bahwa LKS IPA Terpadu berbasis pemanfaatan laboratorium sangat layak digunakan dalam proses pembelajaran dan dapat meningkatkan hasil belajar siswa.
\end{abstract}

Kata Kunci: Hasil belajar, IPA Terpadu, laboratorium, LKS

Abstract: the IPA is a science that studies the concepts, processes, and the fact that there is in nature. IPA occupy an important role in education. IPA directly related to existing problems in the daily life of the life process, interactions with the environment and the activities that occur in life. Things aspects influenced researchers to develop the student's Worksheet IPA based integrated utilization of laboratory that is not yet the availability of learning materials, a lack of utilization of Integrated Science laboratories as well as the condition of the students who are less active in follow the process of learning the integrated IPA. This research aims to know the feasibility of utilization-based integrated Science laboratory and to find out if the Student Worksheets can enhance student learning outcomes. The research method used is Research and Development. At this stage of validation by the validator component that includes content, language and presentation earned an average score of $97.56 \%$ shows the worksheet this very worthy Students in learning. It supported the response of teachers who achieve $98.33 \%$ and $91 \%$ of the student's response States that the student Worksheet is very interesting and may encourage students to be more active in learning. This Student worksheets can enhance cognitive learning results students achieve 0.71 which is a high increase in criteria. From the analysis it was concluded that IPA Students Worksheets based integrated utilization of laboratory is well worth the use in the learning process and can improve student learning outcomes.

Keywords: results of the study, the integrated IPA, laboratories, Student Worksheets

\section{PENDAHULUAN}

Undang-Undang Nomor 20 Tahun 2003 Tentang Sistem Pendidikan Nasional, pendidikan adalah usaha sadar dan terencana untuk mewujudkan suasana belajar dan proses pembelajaran agar siswa secara aktif mengembangkan potensi dirinya untuk memiliki kekuatan spiritual keagamaan, pengendalian diri, kepribadian, kecerdasan, akhlak mulia, serta keterampilan yang diperlukan dirinya, masyarakat, bangsa dan negara. Pendidikan nasional berfungsi mengembangkan kemampuan dan membentuk watak serta peradaban bangsa yang bermartabat dalam rangka mencerdaskan kehidupan bangsa, mengembangkan potensi siswa agar menjadi manusia yang beriman dan bertakwa kepada Tuhan Yang Maha Esa, berakhlak mulia, sehat, berilmu, cakap, kreatif, mandiri, dan menjadi warga negara yang demokratis serta bertanggung jawab. Mutu pendidikan dipengaruhi oleh aktivitas

\footnotetext{
${ }^{1}$ Sekolah Menengah Pertama Negeri (SMPN) 24 Kota Jambi
} 
pembelajaran yang dilakukan oleh guru dan siswa baik di dalam kelas, di laboratorium, di bengkel kerja, dan di kancah belajar lainnya yang terwujud dalam bentuk hasil belajar nyata yang dicapai oleh siswa berupa nilai rata-rata dari semua mata pelajaran dalam satu semester (Hadis, 2010).

Berdasarkan hasil survey terhadap siswa SMPN 24 Kota Jambi, IPA merupakan salah satu mata pelajaran yang dianggap sulit oleh sebagian besar siswa karena banyak konsep yang memuat tentang ilmu hafalan baik teori maupun rumus. Permasalahan yang sering dihadapi dalam pembelajaran IPA adalah kurang aktifnya siswa untuk ikut andil dalam proses pembelajaran dan kurangnya minat siswa untuk bertanya apabila ada materi yang kurang jelas. Siswa yang merasakan IPA sebagai pelajaran yang sulit disebabkan oleh berbagai hal, salah satunya adalah penyampaian dari guru yang kurang menarik sehingga menjadikan siswa merasa bosan dalam mengikuti pelajaran IPA. Untuk mengatasi hal tersebut, seorang guru dituntut untuk lebih kreatif dan profesional dalam mengajar agar siswa dapat belajar secara efektif dan efisien dalam mencapai prestasi belajar yang maksimal. Guru perlu memilih metode, model serta bahan ajar yang sesuai agar pengajaran guru lebih menarik dan materi yang diterima oleh siswa tidak hanya sekedar sekumpulan konsep.

Pemanfaatan laboratorium memiliki peranan penting dalam mewujudkan efektivitas pembelajaran IPA (Novianti, 2011). Pembelajaran yang dilakukan dengan kegiatan laboratorium, memposisikan siswa seolah-olah siswa sebagai scientist yang melakukan satu eksperimen dalam upaya menemukan hubungan gejala alam. Berdasarkan hasil observasi di SMPN 24 Kota Jambi, menunjukkan bahwa laboratorium IPA kurang dimanfaatkan secara maksimal untuk proses pembelajaran. Aktivitas siswa dalam pembelajaran IPA belum mencerminkan sikap ilmiah, tidak aktif dalam melakukan penemuan dan tidak pernah membuktikan fakta atau konsep yang mereka peroleh dari buku panduan. Kegiatan praktikum untuk kelas VII masih jarang dilakukan, sehingga pengalaman siswa dalam kegiatan laboratorium sangatlah minim. Siswa belum bisa berperan sebagai ilmuwan yang dapat menemukan konsep sendiri dari kegiatan laboratorium tanpa bimbingan dan arahan dari guru. Salah satu yang ditempuh guru untuk mengaktifkan proses belajar dan memberikan pengalaman kepada siswa yaitu dengan menggunakan Lembar Kerja Siswa (LKS). Penggunakan LKS berbasis pemanfaatan laboratorium dapat menentukan keefektifan pembelajaran dengan melakukan praktikum di laboratorium. LKS berbasis pemanfaatan laboratorium merupakan salah satu bahan ajar yang dapat mendukung berlangsungnya pembelajaran IPA dengan melakukan praktikum secara langsung.

LKS memiliki peran yang besar dalam proses pembelajaran karena dapat membantu guru untuk mengarahkan siswa menemukan konsep-konsep melalui aktivitasnya sendiri. Namun, LKS yang digunakan oleh kebanyakan guru adalah LKS yang terdapat pada buku panduan, hanya berupa rangkuman materi dari kompetensi dasar yang ingin dicapai dan kumpulan soal-soal yang kemudian hanya menjadi bahan tugas atau bahan pembelajaran yang sering dimanfaatkan untuk mengisi pada saat jam kosong. Berkaitan dengan penggunaan LKS tersebut, maka diperlukan juga kreativitas seorang guru dalam memodifikasi dan mengembangkan LKS yang dapat menumbuhkan sikap ilmiah pada siswa dan dapat membuktikan fenomena- fenomena alam secara langsung di laboratorium sehingga materi IPA bukan hanya sekedar sekumpulan konsep. Pengembangan LKS berbasis pemanfaatan laboratorium ini diharapkan dapat menciptakan suatu media pembelajaran yang baik untuk menyampaikan materi IPA sehingga dapat mencapai kompetensi yang diinginkan.

\section{METODE PENELITIAN}

Pada penelitian ini yang akan diteliti adalah pengembangan LKS berbasis pemanfaatan laboratorium pada materi ciri-ciri makhluk hidup. Pengujian LKS yang dibuat oleh peneliti akan dilaksanakan di SMPN 24 Kota JambiKudus pada kelas VII A tahun pelajaran 2015/2016. Populasi penelitian adalah siswa kelas VII A SMPN 24 Kota Jambi. Sampel penelitian ditentukan dengan metode random sampling secara classter dari anggota populasi penelitian dengan menghitung menggunakan formula homogenitas dan normalitas dari anggota populasi. Berdasarkan perhitungan yang telah dilakukan populasi yang diambil mempunyai varians yang sama (homogen) dengan data yang terdistribusi normal. Perhitungan tersebut digunakan untuk pengambilan sampel secara random sampling. Sampel yang diambil tersaji dalam table-tabel. Sampel penelitian pengembangan LKS IPATerpadu 
berbasis pemanfaatan laboratorium Penelitian ini juga dilengkapi dengan pembuatan perangkat pembelajaran yang meliputi silabus, Rencana Pelaksanaan Pembelajaran (RPP), angket tanggapan siswa terhadap pembelajaran, angket penilaian kelayakan LKS oleh guru dan validator untuk mengetahui keberhasilan dan kelayakan penggunaan LKS yang telah dikembangkan. Untuk mengetahui peningkatan hasil belajar siswa digunakan alat evaluasi yang berupa soal pre test dan post test. Metode penelitian pengembangan (Research and Development) digunakan untuk menghasilkan produk tertentu, dan menguji keefektifan produk tersebut.

\section{HASIL DAN PEMBAHASAN \\ Proses Pengembangan LKS}

Proses pengembangan LKS IPA Terpadu ini mengacu pada langkah penelitian dan pengembangan yang diadaptasi dari Sugiyono (2010). Langkah awal penelitian dan pengembangan ini adalah pengidentifikasian masalah. Pada tahap ini ditemukan dua permasalahan pokok. Permasalahan pertama tentang belum adanya bahan ajar IPA yang berisi perpaduan materi dari mata pelajaran IPA seperti Fisika, Biologi, maupun Kimia. Dengan kata lain pembahasan materi yang terdapat dalam bahan ajar yang digunakan selama ini masih terpisah-pisah antara Fisika, Biologi, maupun Kimia. Permasalahan yang kedua adalah pemanfaatan laboratorium IPA di sekolah yang belum maksimal dengan kata lain siswa belum dilatih untuk menemukan konsep secara langsung dan mandiri melalui kegiatan praktikum.

Berawal dari permasalahan yang ditemukan, maka dilakukan perencanaan untuk mengembangkan bahan ajar. Bahan ajar yang dikembangkan adalah berupa LKS pembelajaran IPA Terpadu berbasis pemanfaatan laboratoriun yang diterapkan pada tema ciri-ciri makhluk hidup pada kelas VII SMP. LKS ini berisi perpaduan antara materi ciri-ciri makhluk hidup (Biologi) yang dihubungkan dengan materi tentang gerak dan kecepatan (Fisika) dan materi nama unsur dan senyawa sederhana pada proses respirasi dan fotosintesis (Kimia). LKS ini berbasis pemanfaatan laboratorium dimana isi LKS terdiri dari 5 kegiatan praktikum yang dilaksanakan di laboratorium dilengkapi dengan 4 kegiatan diskusi tentang tema ciri-ciri makhluk hidup. Kegiatan praktikum dalam LKS antara lain adalah: gerak dalam kehidupan sehari-hari, pernapasan manusia, pernapasan pada hewan dan tumbuhan, hasil proses fotositesis, dan rangsangan panas.

Sistematika kegiatan praktikum dalam LKS adalah: masalah, tujuan, landasan teori, alat dan bahan, cara kerja, pertanyaan, dan kesimpulan. Contoh kegiatan praktikum dalam LKS IPA Terpadu berbasis pemanfaatan laboratorium dapat dilihat pada Gambar 1.
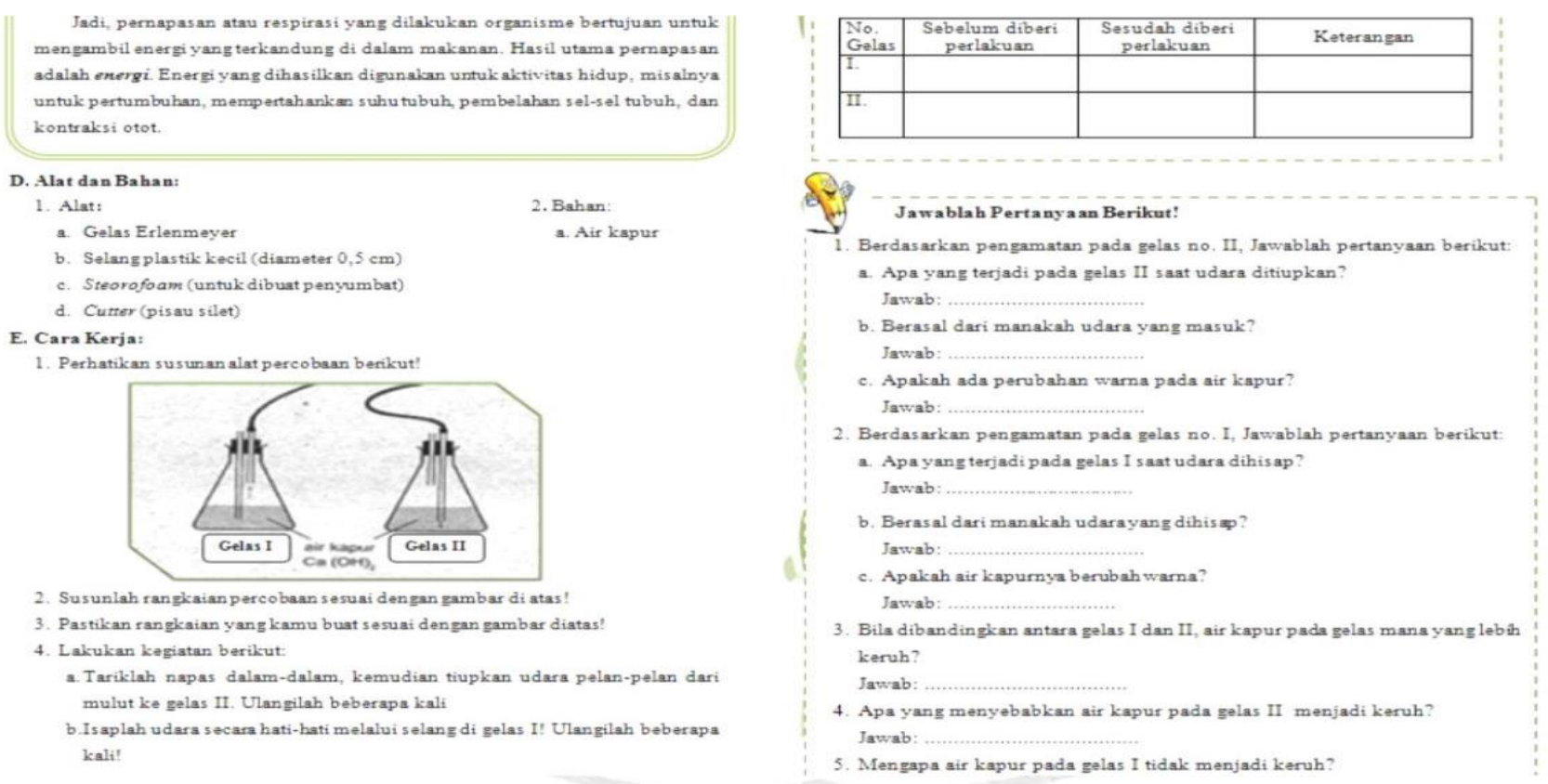

Gambar 1.

Desain Kegiatan Praktikum dalam LKS IPA Terpadu Berbasis Pemanfaatan Laboratorium 
Kegiatan diskusi dalam LKS meliputi: reproduksi, adaptasi, dan ekskresi. Sistematika kegiatan diskusi dalam LKS adalah: masalah, tujuan, landasan teori, pertanyaan pengantar diskusi, dan kesimpulan. LKS ini dilengkapai dengan kata pengantar, daftar isi, standar kompetensi, kompetensi dasar, materi, indikator, dan peta materi. Contoh kegiatan diskusi dapat dilihat pada Gambar 2.

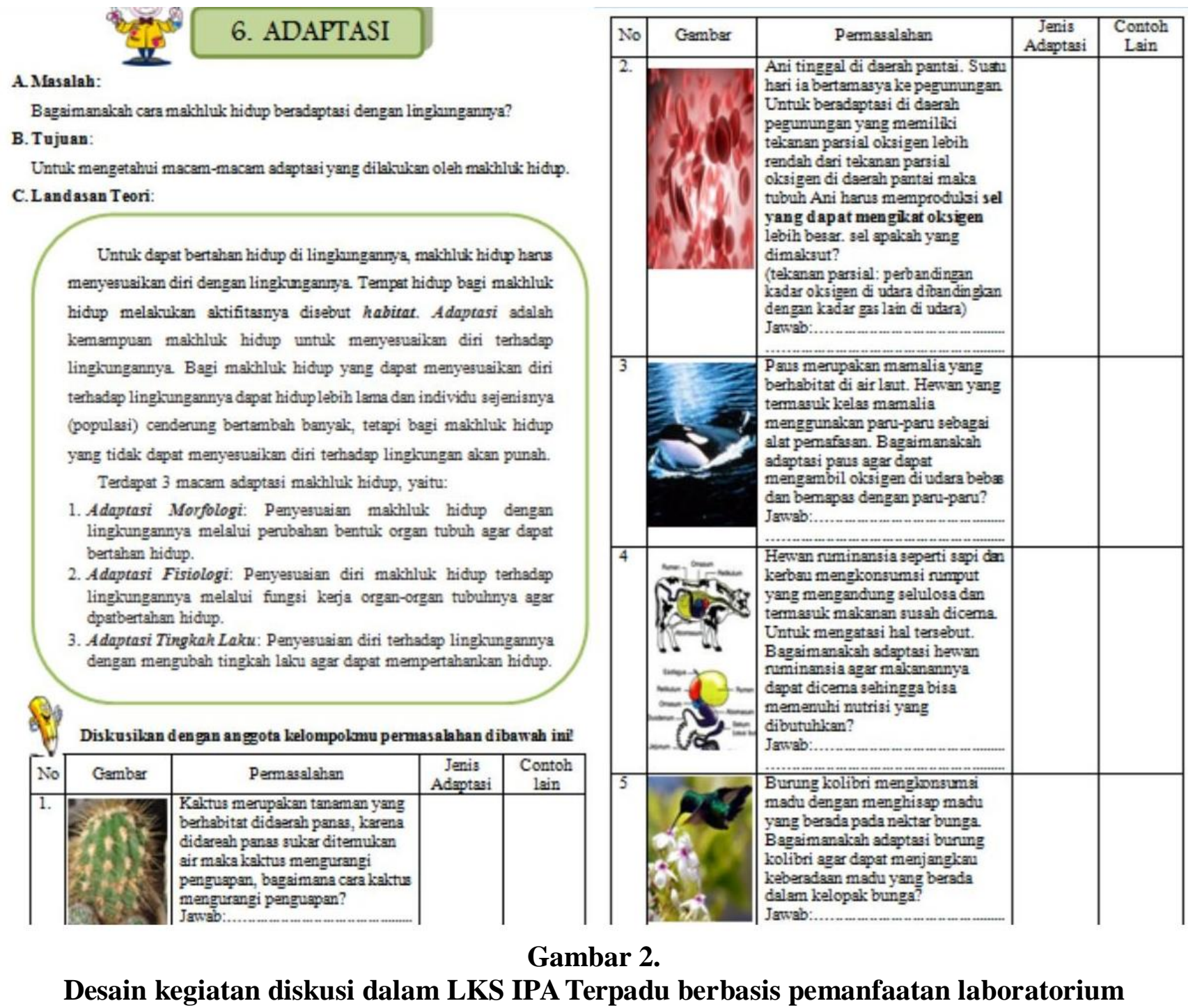

Desain LKS IPA Terpadu berbasis pemanfaatan laboratorium ini kemudian divalidasi oleh tiga orang ahli yang meliputi satu dosen dan satu orang guru dari SMPN 24 Kota Jambi. Setelah LKS dinyatakan layak berdasarkan hasil validasi oleh ahli, LKS ini kemudian diujicobakan kepada 10 orang siswa kelas VIIA A yang dipilih secara acak untuk mengetahui tanggapan siswa terhadap LKS berbasis pemanfaatan laboratorium. Dalam uji coba skala terbatas masih ditemukan beberapa kekurangan yang ada dalam LKS IPA Terpadu berbasis pemanfaatan laboratorium ini. Untuk mengatasi kekuranga dalam LKS dilakukan revisi berupa penggunaan kata baku, penambahan keterangan ilustrasi pada gambar yang mampu memudahkan siswa untuk melakukan kegiatan praktikum. Namun untuk kekurangan mengenai kurangnya pemahaman siswa terkait pertanyaan-pertanyaan yang mengarah pada penarikan kesimpulan tidak dilakukan revisi kalimat pertanyaan. Untuk mengatasi kekurangan ini diperlukan peran guru sebagai mediator untuk menjelaskan maksud dari pertanyaan tersebut secara utuh sehingga siswa dapat memahami maksud dari pertanyaan tersebut. Uji sekala luas digunakan untuk mencari data peningkatan hasil belajar siswa yang diperoleh dengan metode pre test post test. Pada tahap uji skala luas masih ditemukan kekurangan dalam LKS yaitu penggunaan kata yang kurang tepat, sehingga dilakukan revisi pada LKS IPA Terpadu berbasis pemanfaatan laboratorium dengan kata-kata yang dianggap lebih tepat. 


\section{Kelayakan LKS Berdasarkan Validator}

Hasil penilaian kelayakan LKS IPA Terpadu berbasis pemanfaatan laboratorium pada tema ciri-ciri makhluk hidup oleh ahli yang sekaligus melakukan validasi LKS ditampilkan pada Tabel 1.

Tabel 1.

Data hasil validasi kelayakan LKS IPA Terpadu berbasis pemanfaatan laboratorium

\begin{tabular}{|c|c|c|c|c|c|c|}
\hline \multirow{2}{*}{ No } & \multirow{2}{*}{\multicolumn{2}{|c|}{ Validator }} & \multicolumn{3}{|c|}{ Komponen kelayakan } & \multirow{2}{*}{ Persentase (Kriteria) } \\
\hline & & & $\overline{\text { Isi }}$ & Bahasa & Penyajian & \\
\hline 1. & Validator I & 48 & & 20 & 36 & $100 \%$ (sangat layak) \\
\hline \multirow[t]{2}{*}{2.} & Validator II & 47 & & 17 & 35 & $95,19 \%$ (sangat layak) \\
\hline & & Rat & & & & $97,56 \%$ (sangat layak) \\
\hline
\end{tabular}

\section{Kelayakan LKS Berdasarkan Validator}

Hasil penilaian kelayakan LKS IPA Terpadu berbasis pemanfaatan laboratorium pada tema ciri-ciri makhluk hidup oleh ahli yang sekaligus melakukan validasi LKS ditampilkan pada Gambar 3.

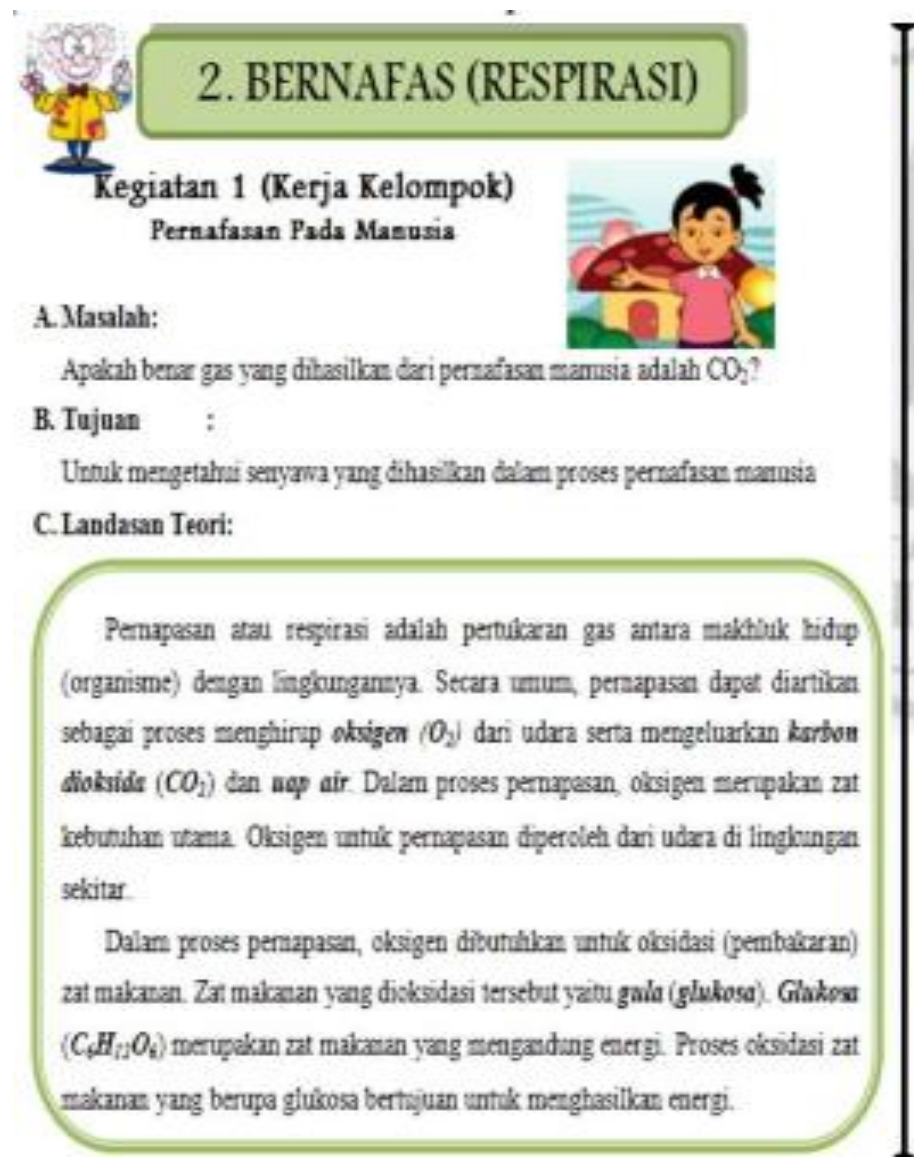

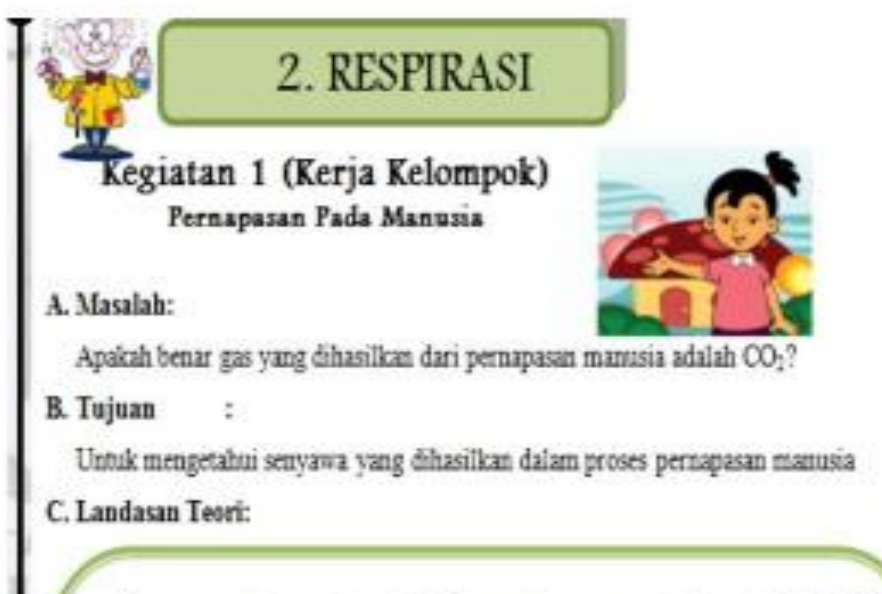

Penapasa ata respirasi adalah pertukare gas antara makbivk hidp (organisme) dengan lingknganyz. Secan umm, pernapasan degat diartikan sebagai proses menghirap oksigen $\left(O_{2}\right)$ dan adara serta mengeluakm karbon diaknida $\left(\mathrm{CO}_{2}\right)$ dan uop air. Dalam proses pernagesan, oksigem merupakan zat stburhan utana Oksigen unak pertapasan diperoleh dari uiara di linghangan sekitar.

Dalam proses perapasan, oksigen dibutulkan untk cksdasi (pembakaran) zat makanm. Zat makanan yang dioksidasi tersebut yazu galo (glukass). Giskosa $\left(C_{6} H_{2} O_{i}\right)$ merupakan zat makanan yang meugandung energi. Proses obsidasi zat makanan yang berupa glukosa bertujuan untuk menghasilkat energi.

\section{Gambar 3.}

\section{Desain penulisan istilah dalam LKS IPA terpadu berbasis}

Selain penggunaan kata baku dan istilah yang sesuai dengan konteks kalimat, Validator II juga menyarankan untuk menambah keterangan pada gambar.Untuk contoh revisi keterangan pada LKS IPA Terpadu dapat dilihat dalam gambar 4. 


\section{Cara Kerja}

1. Süpkan alat dar bahan z̧ang diperiukan'

2. Rebralah air dalam gelas kimia hingga meadida!

3. Masukkan dan berwana hjaj kadalam gelas kimia hingga dan menjadi lembek

4. Masulkan allohol kedalam tabung reaksi kemudian di tim pada gelas kimia Fang berisi air mendidih, masukkan dan yang telah lembek kedalam tabung reaks yang berixi alcobol hingga warsa dam menjadi putih keabu-abuxe

5. Ambil dan dergan pinset kemutian cuci dergan air bersih!

6. Letaikan dam poda cawan kemudian teteskan 3 tetes larutan hool se dam dan amati percbahan pada dam.

7. Ulangi langkah ke $3-5$ un:kx dain yarg berwarna luning langkab 3 - langkah 6 dapat dilihat pada gambar berikut

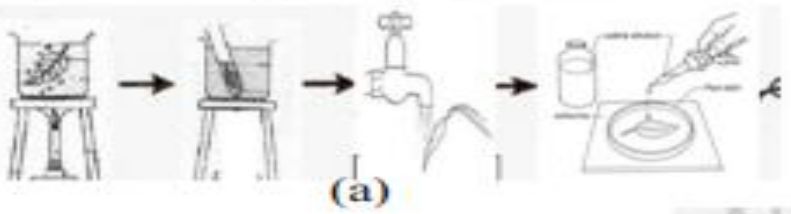

\section{Cara Kerja}

1. Siapkan alat dan bahan yang diperhikan!

2. Rebuslak air dalam gelas kimia hingga mendidih!

3. Masukkan dam berwana hijan be dalam gelas kimia hingga daun menjadi tembek.

4. Masukkan allohol ke dalam tabung reaksi kemodian di tim pada gelas kimia yang berisi air mendidih, masukkan daun yang telah lembek ke dalam tabung reaksi yang berisi alkohol hingga warna daun menjadi putih keabu-abuan.

5. Ambil dain dengan pinset kenudian cuci dengan air bersib!

6. Letakkan dam pada cawan kemodian teteskan 3 tetes larutan lugol ke dam dan amati perubahan pada dam

7. Ulangi langkah ke 3-6 untuk daun yang berwarna kaning langkah 3 - langkah 6 dapat dilihat pada gambar berikut:

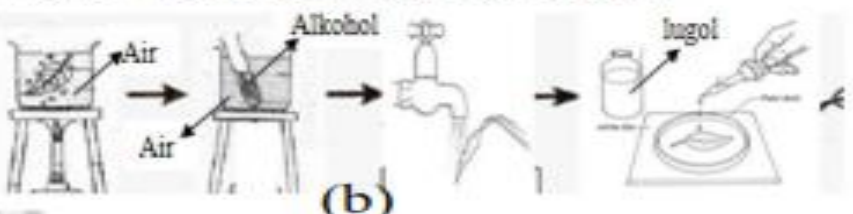

Gambar 4.

Desain keterangan gambar pada LKS IPA Terpadu berbasis pemanfaatan laboratorium sebelum direvisi (a) dan sesudah direvisi (b).

\section{Data Hasil Tanggapan Guru}

Data mengenai tanggapan guru terhadap LKS IPA Terpadu berbasis pemanfaatan laboratorium diperoleh dengan menggunakan angket. Pengisian angket dilakukan setelah mengetahui proses pembelajaran dengan menggunakan LKS. Angket berisi tentang penampilan, perumusan tujuan pembelajaran, sistematika materi, keterpaduan konsep IPA, petunjuk kegiatan dalam LKS, soalsoal dalam LKS, penyajian LKS, gambar dalam LKS, bahasa dan penyesuaian alokasi waktu. Berdasarkan tanggapan guru penialaiannya tersaji dalam Gambar 5.

\footnotetext{
Kegiatan 2 (Kerja Kelompok) Pernafasan Fads Hewan dan Tumbuhan

A. Masalah:

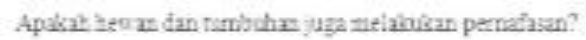

B. Trjuan:

Unok meagetahu yenafasan kevan dan tumblum serta nescan keceporan pernaciazan tersebut

C. Landasan Tear:

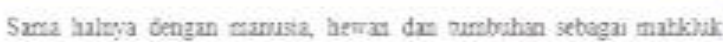

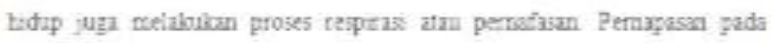

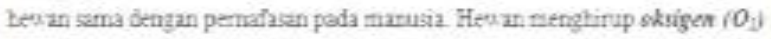

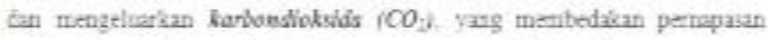
remisa dengur bevan adalit dar pernaposcanye Slansa berropas dengan

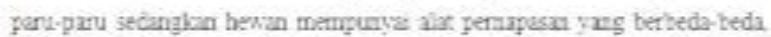

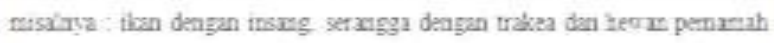
beak sepero sagt bercapas tengan pro-parl.

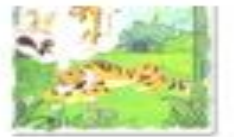

(a)

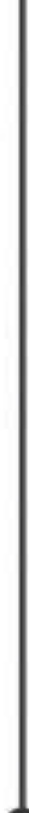

Kegiatan 2 (Kerja Kelompok)

Persapasan Pada Hewan dan Tumbuhan

A. Masalab:

Apeliat heuan dan tumbihas ypa melikukan peruapesas?

B. Tujuan:

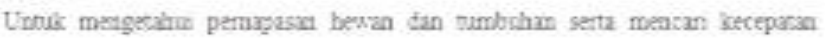
pernapasan tersebre.

C. Landasan Teori:

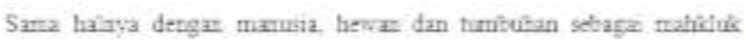

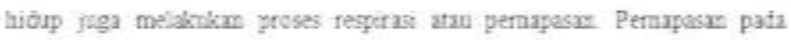
lew an sama dengu pernafasa pada mamisia Hewan menghireg oksigev $\left(O_{3}\right.$

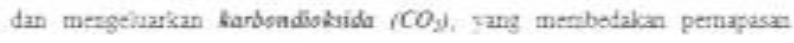

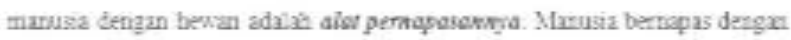
paru-paru sedangion hewas mempuryal ala pernapesas yang berbeda-betz mistinva : ikat dengen insang, serangga deugan trabea dan bevan pertamin biak seperti sapi bernmes dengin paru-paru

(b)

Gambar 5.

Desain penulisan kata baku pada LKS IPA Terpadu berbasis pemanfaatan laboratorium sebelum direvisi (a) dan sesudah direvisi (b). 


\section{Data hasil tanggapan siswa}

Data mengenai tanggapan siswa diperoleh dengan menggunakan angket tanggapan siswa pada tahap uji kelas terbatas. Hasil analisis tanggapan siswa disajikan pada Tabel 2.

Tabel 2.

Data hasil tanggapan siswa terkait LKS IPA Terpadu berbasis pemanfaatan laboratorium

\begin{tabular}{|c|c|c|c|}
\hline No. & Aspek yang ditanyakan & Presentase & Kriteria \\
\hline 1 & $\begin{array}{l}\text { Persetujuan penggunaan LKS IPA Terpadu berbasis pemanfaatan } \\
\text { laboratorium }\end{array}$ & $100 \%$ & Sangat menarik \\
\hline 2 & $\begin{array}{l}\text { Pemahaman materi dengan menggunakan LKS IPA Terpadu berbasis } \\
\text { pemanfaatan laboratorium }\end{array}$ & $100 \%$ & Sangat menarik \\
\hline 3 & Pemahaman tentang kinerja ilmiah yang disajikan dalam LKS. & $90 \%$ & Sangat menarik \\
\hline 4 & Pemahaman soal-soal dalam LKS untuk menuntun penyimpulan materi. & $70 \%$ & Menarik \\
\hline 5 & Penyajian LKS untuk menarik minat membaca dan memahami materi. & $90 \%$ & Sangat menarik \\
\hline 6 & Penggunaan bahasa LKS yang jelas dan mudah dipahami. & $90 \%$ & Sangat menarik \\
\hline 7 & Penyampaian pesan dan keterangan melalui gambar. & $100 \%$ & Sangat menarik \\
\hline 8 & $\begin{array}{l}\text { Kegiatan LKS membantu menemukan konsep secara langsung } \\
\text { berdasarkan hasil praktikum dan penyesuaian terhadap teori yang ada. }\end{array}$ & $80 \%$ & Sangat menarik \\
\hline 9 & $\begin{array}{l}\text { Kegiatan LKS memotivasi untuk berinteraksi, berkomunikasi dan } \\
\text { bekerjasama. }\end{array}$ & $90 \%$ & Sangat menarik \\
\hline \multirow[t]{2}{*}{10} & $\begin{array}{l}\text { Peningkatan minat belajar dengan menggunakan LKS IPA Terpadu } \\
\text { berbasis pemanfaatan laboratorium. }\end{array}$ & $100 \%$ & Sangat menarik \\
\hline & Rata-rata & $91 \%$ & Sangat menarik \\
\hline
\end{tabular}

\section{Peningkatan Hasil Belajar Kognitif}

Untuk mengetahui peningkatan hasil belajar kognitif siswa dalam penelitian ini menggunakan metode pre test-post test. Rata-rata pre test dan post test dapat dilihat dalam Tabel 3.

Tabel 3.

Perhitungan rata-rata nilai pre test dan post test sampel penelitian

\section{Jumlah nilai 34 siswa Rata-rata}

\begin{tabular}{ccccc}
\hline \multirow{2}{*}{ Pre test } & Post test & Pre test & Post test & \multirow{2}{*}{ Faktor gain (kiteria) } \\
\hline 1940 & 2970 & 57,06 & 87,35 & 0,71 (tinggi) \\
\hline
\end{tabular}

Peningkatan hasil belajar kognitif siswa dihitung dengan menggunakan rumus gain ternormalisasi dan faktor gain yang diperoleh adalah 0,71dan masuk dalam kriteria peningkatan yang tinggi. Untuk mengetahui tarat signifikan yang dihasilkan dari perbandingan nilai pre test dan post test digunakan uji-t. Sebelum dilakukannya uji-t, kenormalan dan kesamaan nilai pre test dan post test di analisis dengan rumus normalitas dan homogenitas. Dari hasil analisis diketahui bahwa nilai pre test dan post test siswa terdistribusi normal dan keduanya bersifat homogen. Hasil perhitungan uji normalitas untuk nilai pretest dan postest dapat dilihat pada tabel 4.

Tabel 5.

Hasil uji normalitas nilai pretest dan postest terhadap penggunaan LKS IPA Terpadu berbasis pemanfaatan laboratorium.

\begin{tabular}{|c|c|c|}
\hline Aspek & $\mathrm{x}^{2}$ hittung & $\mathrm{x}^{2}$ tabel \\
\hline Pretest & 10,43 & 11,07 \\
\hline Postest & 10,70 & 11,07 \\
\hline
\end{tabular}

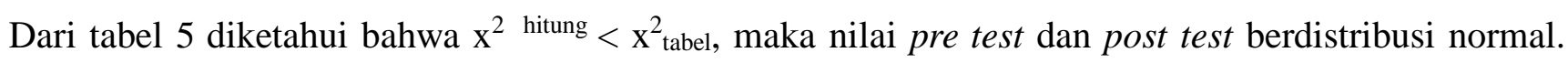


Selanjutnya dilakukan uji-t untuk nilai pre test dan post test. Hasil perhitungan uji-t dapat dilihat pada tabel 6.

Tabel 6.

Hasil uji-t nilai pretest dan postest terhadap penggunaan LKS IPA Terpadu berbasis pemanfaatan laboratorium

Jumlah siswa

pretest $=34$

postest $=34$

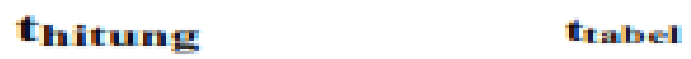

$$
12,64 \quad 0,344
$$

Dari hasil perhitungan $t_{\text {hitung }}>\mathrm{t}_{\text {tabel }}$ maka terdapat perbedaan yang signifikan antara rata-rata nilai pretest dengan postest.

\section{Peningkatan Hasil Belajar Siswa}

Hasil belajar siswa dilihat dari nilai post test yang diperoleh masing-masing siswa. Dari 34 siswa terdapat 2 siswa yang mendapatkan nilai terrendah yaitu 75 dan 4 siswa mendapatkan nilai 100 yang merupakan nilai tertinggi. Untuk hasil belajar siswa dapat dilihat dalam Tabel 4.7.

Tabel 7.

Perbandingan nilai pre test dan post test.

\begin{tabular}{lcc}
\hline \multicolumn{1}{c}{ Aspek } & Pretest & Post test \\
\hline Jumlah siswa & 34 & 34 \\
Nilai tertinggi & 85 & 100 \\
Nilai terendah & 25 & 75 \\
Siswa yang tuntas & 2 & 32 \\
Siswa yang tidak tuntas & 32 & 2 \\
Ketuntasan klasikal & $5,88 \%$ & $94,12 \%$
\end{tabular}

\section{Pembahasan}

\section{Kelayakan LKS IPA Terpadu Berdasarkan Validator}

Kelayakan LKS IPA Terpadu berbasis pemanfaatan laboratorium ini diukur dengan menggunakan instrumen angket. Penilaian kelayakan LKS dilakukan oleh dua validator yang terdiri dari satu dosen dan satu guru IPA kelas VII SMP Negeri 24 Kota Jambi. Dari penilaian kedua validator ini diperoleh nilai kelayakan LKS sebesar $100 \%$ dan $95,15 \%$. Sehingga nilai rata-rata kelayakan modul pembelajaran adalah sebesar 97,56\% yang dapat ditarik kesimpulan bahwa LKS IPA Terpadu berbasis pemanfaatan laboratorium pada tema ciri-ciri makhluk hidup sangat layak untuk diterapkan dalam pembelajaran di kelas VII SMPN 24 Kota Jambi. Komponen LKS yang dinilai meliputi komponen kelayakan isi, bahasa, dan penyajian. Pada komponen kelayakan isi, kedua validator memberikan skor $\geq$ 3 pada setiap butir komponen. Hal ini menunjukan bahwa kegiatan dalam LKS , kedalaman cakupan materi dan sistematika penyusunan LKS sudah baik. Materi yang disajikan sesuai dengan standar kompetensi (SK) dan kompetensi dasar (KD), dapat menumbuhkan rasa ingin tahu siswa, memudahkan siswa dalam belajar dan lebih aktif dalam proses belajar. Kegiatan-kegiatan LKS sudah membimbing siswa untuk menemukan konsep secara mandiri. Namun, masih ada saran dari salah satu validator untuk menegaskan tugas dari masing-masing siswa dalam kegiatan praktikum agar siswa lebih aktif. 
Untuk menegaskan tugas dari masing-masing siswa disini diperlukan peran guru sebagai mediator, pengarah dan pembimbing siswa untuk melakukan kegiatan dalam LKS IPA Terpadu berbasis pemanfaatan laboratorium khususnya dalam kegiatan praktikum. Pada komponen penilaian kelayakan bahasa, kedua validator memberikan skor $\geq 3$ pada setiap butir komponen. Hal ini berarti bahwa bahasa yang digunakan dalam LKS komunikatif dan sesuai dengan tingkat perkembangan siswa. Selain itu LKS juga menggunakan istilah-istilah ilmiah yang konsisten sehingga siswa dapat memahami dengan baik. Akan tetapi, salah satu validator memberikan saran agar mengevaluasi kembali LKS terkait dengan penulisan kata baku dan penempatan istilah ilmiah berdasarkan konteks kalimat agar bahasa dalam LKS lebih sempurna. Istilah ilimiah yang digunakan hendaknya dipilih istilah yang mudah dipahami oleh siswa dan penempatan istilah yang tepat sesuai konteksnya agar siswa tidak merasa kebingungan. Pada komponen penilaian kelayakan penyajian, kedua validator memberikan skor $\geq 3$ pada setiap butir komponen. Hal ini menunjukkan bahwa LKS yang dikembangkan ini mempunyai desain menarik, memuat ilustrasi baik gambar maupun kalimat yang memudahkan siswa dalam memahami materi yang disajikan. Ilustrasi berupa gambar dapat menumbuhkan ketertarikan siswa untuk mempelajari materi yang ada didalamnya. Gambar yang disajikan merupakan gambar yang sesuai dan mempunyai hubungan terhadap materi yang disajikan dalam LKS. Namun masih perlu ditambahkan keterangan pada gambar untuk penentuan keberhasilan kegiatan praktikum.

\section{Tanggapan Guru Terhadap LKS IPA Terpadu}

Tanggapan guru terhadap LKS IPA Terpadu berbasis pemanfaatan laboratorium diperoleh setelah guru melaksanakan pengajaran menggunakan LKS ini, yaitu pada saat selesai pembelajaran dalam skala kecil. Tanggapan guru diperoleh dari pengisian angket. Guru memberikan skor 4 pada 14 butir komponen dari 15 butir komponen. Empat belas komponen tersebut meliputi penampilan, perumusan tujuan pembelajaran, sistematika, keterpaduan konsep, penilaian kegiatan, penyesuaian alokasi waktu, dan isi LKS. Terdapat 1 butir komponen yang diberi skor 3 yaitu terkait bahasa dalam LKS, karena terdapat penulisan 1 kata tidak baku didalam LKS yaitu — nafas\| yang seharusnya —napas\|.

Berdasarkan tanggapan dari guru, LKS IPA Terpadu berbabasis pemanfaatan laboratorium ini dinyatakan sangat layak digunakan dalam pembelajaran dengan prosentase kelayakan 98,33\%. Berdasarkan saran dari guru mata pelajaran IPA di SMPN 24 Kota Jambi, LKS IPA Terpadu direvisi dengan merubah kata-kata tidak baku dalam LKS dengan menggunakan kata-kata baku yang sesuai dengan ejaan yang di sempurnakan. Selain itu guru juga memberikan saran untuk lebih memperhatikan alokasi waktu yang digunakan untuk melaksanakan kegiatan-kegiatan dalam LKS. LKS IPA Terpadu berbasis pemanfaatan laboratorium mempunyai 5 kegiatan praktikum yaitu gerak, pernapasan pada manusia, pernapasan pada hewan dan tumbuhan, hasil proses fotosintesis, dan rangsangan panas dan 4 kegiatan diskusi. Dari 5 kegiatan praktikum dan 4 kegiatan diskusi tersebut hendaknya alokasi waktu yang disediakan dilaksanakan dengan seefektif mungkin agar semua kegiatan dapat dilaksanakan.

\section{Tanggapan Siswa Terhadap LKS IPA Terpadu}

Tanggapan siswa mengenai LKS diperoleh pada saat uji coba skala kecil. Skor angket sebesar 91\% diperoleh dari 10 siswa yang menjadi penilai LKS pada tahap ini. Hal ini menunjukkan bahwa LKS IPA Terpadu berbasis pemanfaatan laboratorium pada tema ciri-ciri makhluk hidup sangat menarik untuk diterapkan dalam pembelajaran. Secara umum siswa merasa tertarik dengan LKS ini karena LKS yang dikembangkan berbeda dengan LKS atau bahan ajar yang sudah ada. Penyusunan LKS secara IPA Terpadu dapat menambah pengetahuan siswa meliputi bidang fisika, kimia dan biologi dalam 1 tema. LKS ini membantu siswa untuk menemukan konsep secara mandiri melalui kegiatan praktikum dan diskusi yang termuat dalam kegiatan kegiatan dalam LKS. Kegiatan praktikum didalam laboratorium dapat memaksimalkan pemanfaatan laboratorium sebagai tempat belajar yang membuat siswa lebih aktif dan dapat menemukan konsep secara mandiri. 


\section{SIMPULAN}

Penelitian ini telah berhasil mengembangkan LKS IPA Terpadu berbasis pemanfaatan laboratorium. LKS IPA Terpadu ini dikembangkan dengan memadukan materi biologi, fisika dan kimia secara integrated dengan tema ciri-ciri makhluk hidup yang diterapkan pada siswa kelas VII SMPN 24 Kota Jambi. Dari hasil penelitian dapat disimpulkan bahwa:(1) LKS IPA Terpadu berbasis pemanfaatan laboratorium pada tema ciri-ciri makhluk hidup untuk kelas VII SMPN 24 Kota Jambi sangat layak untuk digunakan dalam proses pembelajaran. (2) LKS IPA Terpadu berbasis pemanfaatan laboratorium pada tema ciri-ciri makhluk hidup dapat meningkatkan hasil belajar siswa.

\section{DAFTAR PUSTAKA}

Arikunto, Suharsimi. 2010. Prosedur Penelitian Suatu Pendekatan Praktik. Jakarta: Rineka Cipta.

Depdiknas. 2007. Pedoman Memilih Menyusun Bahan Ajar dan Teks Mata Pelajaran dilengkapi: Rencana Pelaksanaan Pembelajaran (RPP) SMP/ MTs. Jakarta: Pusat Kurikulum Balitbang

Depdiknas. 2009. Panduan Pengembangan Pembelajaran IPA Terpadu Sekolah Menengan Pertama/Madrasah Tsanawiyah (SMP/MTs). Jakarta Pusat: Pusat Kurikulum Balitbang Depdiknas.

DPR RI. 2003. Undang-Undang RI No.20 Tahun 2003 Tentang Sistem Pendidikan Nasional. Jakarta: Depdiknas.

Hadis, Abdul. 2010. Manajemen Mutu Pendidikan. Bandung: Alfa Beta.

Karim, Saeful, Ida NF \& Wahyu S. 2009. Belajar IPA Membuka Cakrawala Alam Sekitar untuk Kelas VII SMP/MTs. Jakarta: Pusat Perbukuan Depdiknas.

Majid A. 2005. Perencanaan Pembelajaran. Bandung: PT Remaja Rosdakarya

Novianti, Nur Raina. 2011. Kontribusi Pengelolaan Laboratorium \& Motivasi Belajar Siswa 1412-565X. Terhadap Efektifitas Proses Pembelajaran. Jurnal Pendidikan"Edisi Khusus No. 1" ISSN

sudijono. 2009. Pengantar Evaluasi Pendidikan. Jakarta: Rajawali.

Sugiyono. 2010. Metode Penelitian Pendidikan Pendekatan Kuantitatif, Kualitatif R\&D. Bandung: Alfa Beta.

Suhardi,Suratno \& Pera Tri. 2009. Pembelajaran Ilmu pEngetahuan Alam Terpadu \& Kontekstual VII Untuk SMP/MTs. Jakarta: Pusat Perbukuan, Depertemen Pendidikan Nasional.

Trianto. 2007. Model Pembelajaran Terpadu dalam Teori dan Praktek. Jakarta:Prestasi Pustaka.

.2010. Mendesain Model Pembelajaran Inovatif, Progresif Konsep, Landasan, dan Implementasinya Pada Kurikulum Tingkat Satuan Pendidikan. Jakarta: Kencana. Winarsih, Anny, Nugroho, Sulityoso, Zajuri, Supriyadi \& Suyanto. 2008.

IPA TERPADU untuk SMP/MTs Kelas VII. Jakarta: Pusat Perbukuan, Departemen Pendidikan Nasional. 